\title{
SPRAY DEPOSITION ON SOYBEAN CROP USING DIFFERENT TRAVEL SPEEDS AND APPLICATION RATES
}

\author{
João P. A. R. da Cunha ${ }^{1 *}$, Arthur P. Victor², Caroline G. R. Sales ${ }^{2}$ \\ 1*Corresponding author. Universidade Federal de Uberlândia/ Uberlândia - MG, Brasil. E-mail: jpcunha@ufu.br
}

\section{KEYWORDS}

application

technology, Glycine

max, sprayer.

\begin{abstract}
Farmers are seeking pesticide treatments with lower application rates and higher travel speeds. However, this can lead to a poor quality of the application. The aim of this study was to evaluate the spray deposition on soybean crop and the droplet spectra using different application rates and speeds. The experiment was conducted in soybean (R5 stage), M 6410 IPRO variety. Six treatments involving two application rates (80 and 150 $\left.\mathrm{L} \mathrm{ha}^{-1}\right)$ and three speeds $\left(10,15\right.$ and $\left.20 \mathrm{~km} \mathrm{~h}^{-1}\right)$ were evaluated through a self-propelled sprayer. A characterization study of the spray droplets was conducted through the evaluation of water sensitive papers. The spray deposition study was carried out. For this, a marker was added to the application to be detected by absorbance in spectrophotometry. The use of spray nozzles with higher nominal flow, as well as lower pressures, produced droplets of larger sizes. The application rate of $80 \mathrm{~L} \mathrm{ha}^{-1}$ provided equal and higher spray retention in the lower and upper leaves of the plants, respectively. The three speeds did not influence the deposition on soybean plants.
\end{abstract}

\section{INTRODUCTION}

Despite the high production potential and high availability of soybean varieties (Glycine $\max (\mathrm{L}$.$) Merrill)$ with characteristics that allow their adaptation to the different regions, it is sometimes observed low and irregular production. This is attributed, among other factors, to the occurrence of weeds and the constant cycles of pests and pathogens during the development of the crop (Yokomizo et al., 2013). In this context, chemical control has become a fundamental tool for the protection of the genetic potential of plants.

The deposition of the active ingredient inside the canopy is a basic condition for effective control of pests and diseases, and as the crop cycle progresses, reaching the lower layers of the canopy becomes an ever-increasing challenge. Thus, the correct choice of technique and timing of application are important for the deposition of the plant protection product on the target and for the minimization of losses (Tormen et al., 2012; Berger-Neto et al., 2017).

The spray nozzles are important constituents of sprayers, directly affecting the quality and safety of the application process. For soybean cultivation, nozzles that produce fine droplet spectrum are widely used (VMD < $177 \mu \mathrm{m})$. However, nozzles that produce larger droplets (VMD> $218 \mu \mathrm{m}$ ), such as pre-orifice and air-induction nozzles, are also used to minimize drift. These, on the other hand, may compromise canopy cover and reduce the effectiveness of disease and pest control when used improperly (Cunha et al., 2014). Berger-Neto et al. (2017) showed that air induction nozzles were efficient to control soybean diseases. Baio et al. (2016) obtained good results of spray deposition in different extracts of soybean plants with this type of nozzles.

The application rate is a very important variable in the application of plant protection products. The current trend is its reduction, however, the use of less volume of water mixed with the active ingredient requires optimization of the application technology to ensure a good coverage of the desired target (Bueno et al., 2014; Baio et al., 2016).

Linked to the reduction of the application rate is the increase of the speed. This increase, much desired by farmers, influences the transport time of the droplets produced by the spray nozzle to the biological target and, consequently, the potential for losses or drift to the environment and the application efficiency (Liu et al., 2006). Thus, more studies are necessary to evaluate the feasibility of using application speeds greater than $18 \mathrm{~km}$ $\mathrm{h}^{-1}$, combined with application rates of the order of $80 \mathrm{~L}$ $\mathrm{ha}^{-1}$, since most of the research already performed, for example of Berger-Neto et al. (2017) and Baio et al. (2016), were performed at speeds of less than $8.0 \mathrm{~km} \mathrm{~h}^{-1}$.

\footnotetext{
${ }^{2}$ Universidade Federal de Uberlândia/ Uberlândia - MG, Brasil.

Received in: 12-20-2016

Accepted in: 6-30-2017
} 
Therefore, this study was conducted with the aim of evaluating the spray deposition in the soybean crop and the spectrum of droplets promoted by spraying at different speeds and application rates.

\section{MATERIAL AND METHODS}

The experiment was conducted at Boa Esperança farm, located in the municipality of Uberaba, Minas Gerais, at an altitude of 954 meters, 19 10'38.32'S latitude and $47^{\circ} 51^{\prime} 07.13^{\prime \prime} \mathrm{W}$ longitude. The area presents flat topography and soil with clayey texture. The experiment was carried out on the second application of fungicides in the area, under soybean cultivation, with a line spacing of $0.5 \mathrm{~m}$ and 18 plants per linear meter in the R5 stage, M 6410 IPRO variety, in the 2014/15 harvest.

The application was carried out during the reproductive cycle of the soybean crop and within the period considered critical for the occurrence and development of pest-insects and end-of-cycle diseases. The spray was prepared using the Elatus ${ }^{\mathrm{TM}}$ fungicide (azoxystrobin $300 \mathrm{~g}$ a.i. $\mathrm{kg}^{-1}+$ benzovindifluup $150 \mathrm{~g}$ a.i. $\left.\mathrm{kg}^{-1}\right)$ at a dose of $200 \mathrm{~g} \mathrm{ha}^{-1}$ and the Nimbus ${ }^{\mathrm{TM}}$ adjuvant (aliphatic hydrocarbon $428 \mathrm{~g}$ a.i. $\mathrm{L}^{-1}$ ), at the concentration of $0.5 \mathrm{~L}$ to 100 liters of spray.

Each treatment occupied an area of 3,000 $\mathrm{m}^{2}$, being $100 \mathrm{~m}$ of long and $30 \mathrm{~m}$ of wide. Aiming for greater uniformity of results, the initial and final $25 \mathrm{~m}$ of each treatment were not considered for sampling, since the sprayer needed to reach the predetermined speed.

A self-propelled spray of Case IH brand, Patriot 350 model, equipped with a 3,500 L tank with a spray boom of $30 \mathrm{~m}$ was used. It was used spacing among nozzle and application height in relation to the crop of $0.5 \mathrm{~m}$. The travel speeds, as well as application rates, are given in Table 1. Different nozzles and pressures were used to allow the application of the predetermined spray volume for each treatment. The nozzles used, manufactured by Micron Sprayers, were twin flat with air induction (AIR), with a $110^{\circ}$ jet opening angle and a recommended pressure range of 200 to $700 \mathrm{kPa}$.

TABLE 1. Description of the treatments evaluated.

\begin{tabular}{|c|c|c|c|c|}
\hline Treatment & $\begin{array}{l}\text { Travel speed } \\
\left(\mathrm{km} \mathrm{h}^{-1}\right)\end{array}$ & $\begin{array}{c}\text { Application rate } \\
\left(\mathrm{L} \mathrm{ha}^{-1}\right)\end{array}$ & Spray nozzles* & $\begin{array}{c}\text { Working pressure } \\
(\mathrm{Psi} / \mathrm{kPa})\end{array}$ \\
\hline 1 & 10 & 150 & $\begin{array}{c}\text { Micron } \\
\text { AIR } \\
11002^{* *}\end{array}$ & $100 / 689$ \\
\hline 2 & 15 & 150 & $\begin{array}{c}\text { Micron } \\
\text { AIR } \\
11003^{* *}\end{array}$ & $100 / 689$ \\
\hline 3 & 20 & 150 & $\begin{array}{c}\text { Micron } \\
\text { AIR } \\
11004^{* *}\end{array}$ & $100 / 689$ \\
\hline 4 & 10 & 80 & $\begin{array}{c}\text { Micron } \\
\text { AIR } \\
11002^{* *}\end{array}$ & $30 / 207$ \\
\hline 5 & 15 & 80 & $\begin{array}{c}\text { Micron } \\
\text { AIR } \\
11003^{* *}\end{array}$ & $30 / 207$ \\
\hline 6 & 20 & 80 & $\begin{array}{c}\text { Micron } \\
\text { AIR } \\
11004^{* *}\end{array}$ & $30 / 207$ \\
\hline
\end{tabular}

*Manufacture: MICRON.

${ }^{* *}$ Twin flat spray nozzles with air induction.

A characterization study of the spray droplets was carried out by evaluating the droplets deposited on water sensitive papers (76 x $26 \mathrm{~mm}$ ) (Syngenta, Basel). Ten water-sensitive papers were used for each treatment, kept horizontal and facing up, at the height of the last trefoil. After the application, they were collected and stored in envelopes, free of humidity, for further quantification and characterization of the impacts of each paper. Due to the different application rates, this study aimed to characterize only the droplet spectrum and not the deposition of the spray, which was evaluated through a tracer.

In order to read the papers, they were scanned (spatial resolution of 600 dpi non-interpolated, with 24-bit color) and analyzed using the CIR 1.5 computer program (Counting and Typing of Spray Impacts), specific for this purpose. The volumetric median diameter (VMD or Dv0.5), relative amplitude (RA) and percentage of the spray volume present in spray droplets less than $100 \mu \mathrm{m}$ $(\%<100)$ were determined.

The study of the spray deposition in soybean plants was carried out by the addition of the Blue Brilliant food marker (internationally labeled "Food, Drug \& Cosmetic" as FD\&C Blue No. 1) to the application spray at $300 \mathrm{~g} \mathrm{ha}^{-1}$ (adjusting the amount of the dye added to the tank depending on the application volume used), to be detected by absorbance in spectrophotometry.

Immediately after application of the spray in each treatment, ten samples, containing three leaves of each replicate, were collected from both upper and lower parts of randomly selected soybean plants. The leaves were conditioned in plastic bags, separated according to the position in the plant, and stored in a thermal box for later manipulation in the laboratory. 
In the laboratory, $100 \mathrm{~mL}$ of distilled water was added to each plastic bag containing the soybean leaves. These were closed and shaken for $30 \mathrm{~s}$ to homogenize the dye present in the samples. Next, the liquid was removed and transferred to plastic cups, which were conditioned in a refrigerated room equipped with a light insulation for 24 hours for further reading of the absorbance in the spectrophotometer, similar to that carried out by Bueno et al. (2014).

A spectrophotometer (Electric Filter Photometer, Biospectro, SP-22 Model) was used, with a tungstenhalogen lamp to perform the readings. The color quantification was done by absorbance at $630 \mathrm{~nm}$, the detection range of the blue marker used.

The foliar area was determined using a foliar area meter, ADC BioScientific Ltda brand, AM 300 model. Using the calibration curve, obtained by standard marker solutions, the absorbance data were transformed into concentration (mg $\left.\mathrm{L}^{-1}\right)$. From the initial spray concentration and the dilution volume of the samples, the dye mass retained in the soybean leaves collected in the treatments was determined. The total deposit was divided by the leaf area of each sample, thus obtaining the amount in $\mu \mathrm{g}$ of dye per $\mathrm{cm}^{2}$ of leaf area. To compare the uniformity of distribution along the canopy, we used an index given by the quotient between upper and lower deposition (Cunha et al., 2011).

The environmental conditions during the applications were monitored by a digital thermohygrometer (Kestrel ${ }^{\circledR} 4000$ ). The temperature ranged from 22.8 to $26.5^{\circ} \mathrm{C}$; the relative air humidity ranged from 60.6 to $76.0 \%$ and wind speed ranged from 3.0 to $5.4 \mathrm{~km} \mathrm{~h}^{-1}$.

The experiment, due to the large size of each experimental plot, did not follow a standard design. Thus, following the methodology by Souza et al. (2002) and Antuniassi et al. (2011), droplet spectra data and spray deposition were compared by the statistical method "Confidence Interval for Differences Between Averages" with a $90 \%$ confidence interval $\left(\mathrm{CI}_{90 \%}\right)$, considering ten replicates for each treatment.

\section{RESULTS AND DISCUSSION}

In Figure 1, there are the results of the volumetric median diameter (VMD). The averages ranged from 248.55 to $478.70 \mu \mathrm{m}$. These values decreased with the increase of the pressure, since the reduction of the application rate in a same speed was made through the decrease of the pressure. Within the same application rate, there was a difference between the three spray nozzles used for each speed. The 11002 nozzle generated the lowest VMD averages for the volumes of 80 and $150 \mathrm{~L} \mathrm{ha}^{-1}$.

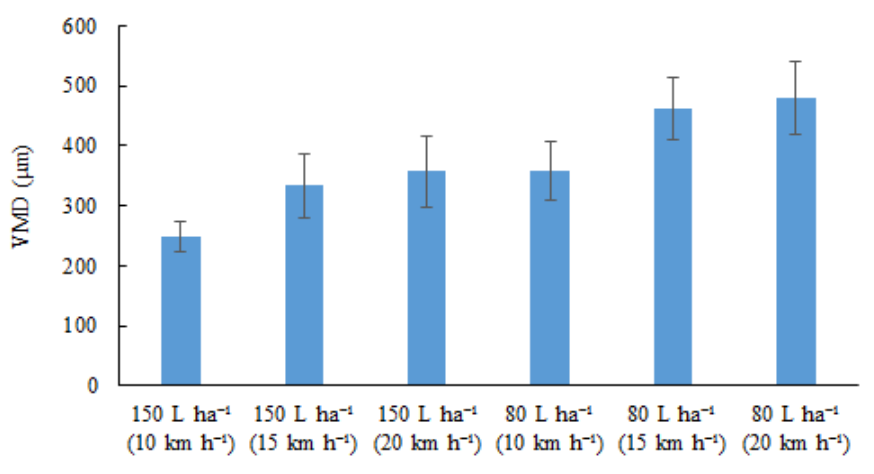

FIGURE 1. Volumetric median diameter (VMD) in function of the application at different speeds and application rates in the soybean crop. The bars indicate the $\mathrm{CI}\left(\mathrm{CI}_{90 \%}\right)$.

The results assumed the same behavior as those achieved by Cunha et al. (2004), evaluating flat fan nozzles. According to these authors, the increase in the exit orifice at the nozzles, associated with lower pressures, provides a smaller jet break, producing larger diameter droplets.

The interpretation of the percentage data of the volume formed by droplets with a diameter of less than $100 \mu \mathrm{m}(\%<100 \mu \mathrm{m})$ (Figure 2) allows the estimation of the drift potential of the application. In general, values of less than $15 \%$ of droplet volume with a diameter of less than $100 \mu \mathrm{m}$ may imply more secure spraying (Bueno et al., 2013).In this sense, the different spray nozzles, submitted to the pressures, influenced the percentage of droplets with a diameter of less than $100 \mu \mathrm{m}$. The airinduction twin flat nozzles produced a small percentage of droplets with a diameter of less than $100 \mu \mathrm{m}$, always below $15 \%$.

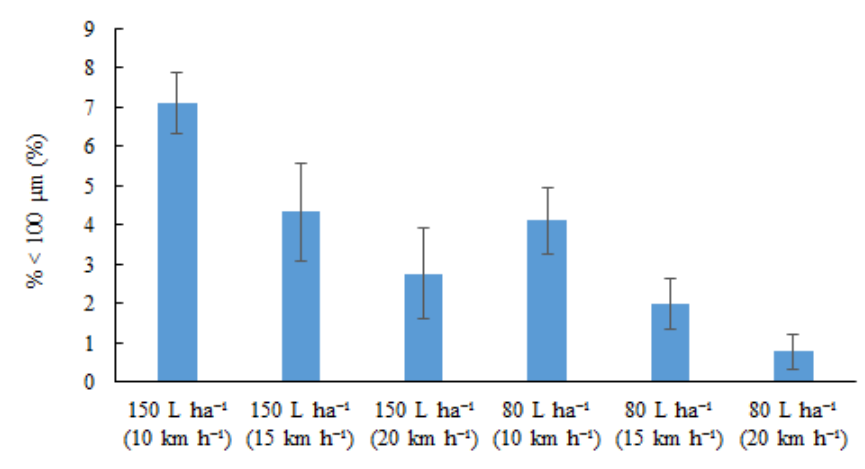

FIGURE 2. Percentage of the spray volume present in spray droplets less than $100 \mu \mathrm{m}(\%<100 \mu \mathrm{m})$ in function of the application at different speeds and application rates in the soybean crop. The bars indicate the $\mathrm{CI}\left(\mathrm{CI}_{90 \%}\right)$.

These nozzles promote the mixing of air with the liquid, so that the droplets produced are larger than those obtained with conventional nozzles of the same flow (Gandolfo et al., 2013).Corroborating with this study, Madureira et al. (2015) noted that the air induction flat fan nozzle presented lower potential drift risk compared to the flat fan nozzle.

The treatment that used the speed of $10 \mathrm{~km} \mathrm{~h}^{-1}$ at a pressure of $689 \mathrm{kPa}$ (100 Psi) highlights, in which $7.09 \%$ of the sprayed volume had a diameter of less than $100 \mu \mathrm{m}$, differing from the others. Although it was the treatment 
with the highest risk of drift, nevertheless, it presented low potential of risk. Each treatment presents a characteristic confidence interval, which is a function of the variability of the data between the repetitions. From the standard deviation, the error and the confidence interval were calculated.

The relative amplitude reveals the uniformity of the spray droplet spectrum and is directly related to the quality of the application. Relative amplitudes tending to zero indicate more homogeneous droplet spectra (Viana et al., 2010). There was no statistical difference between the treatments for this characteristic (Figure 3).

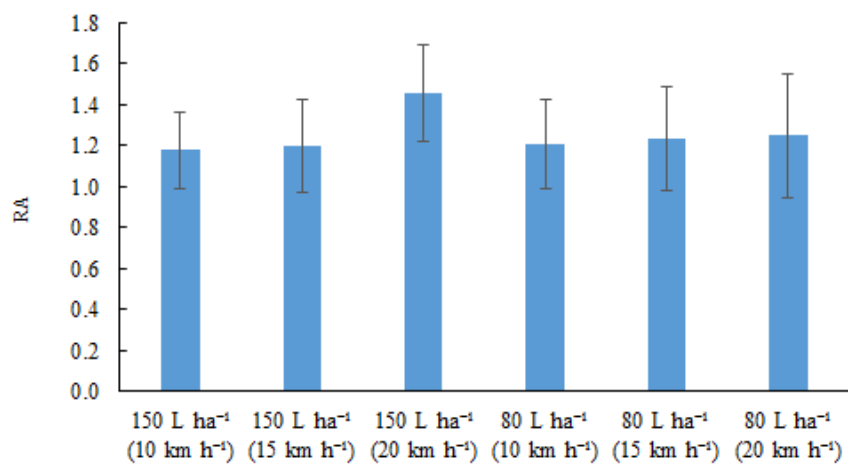

FIGURE 3. Relative amplitude (RA) of the droplet spectrum in function of the application at different speeds and application rates in the soybean crop. The bars indicate the $\mathrm{CI}\left(\mathrm{CI}_{90 \%}\right)$.

Viana et al. (2010) evaluated the volumetric distribution and the droplet spectrum of low drift spray nozzles. These authors found that the air induction nozzles produced a more uniform droplet spectrum compared to the other models used. In this study, since only air induction nozzles were used, there was no difference in the relative amplitude.

The deposition data for the upper canopy of the soybean plants are shown in Figure 4. Within the same application rate, there was no difference in this characteristic. The application rate of $80 \mathrm{~L} \mathrm{ha}^{-1}$, in the two lower speeds, provided a higher retention of the spray when compared to the volume of $150 \mathrm{~L} \mathrm{ha}^{-1}$. In general, the increase in application rate is expected to provide higher canopy deposit up to a certain limit. However, Chechetto et al. (2012) state that the leaf surface has a limited retention capacity and, above this, there is an increase in operation cost and environmental contamination due to runoff.

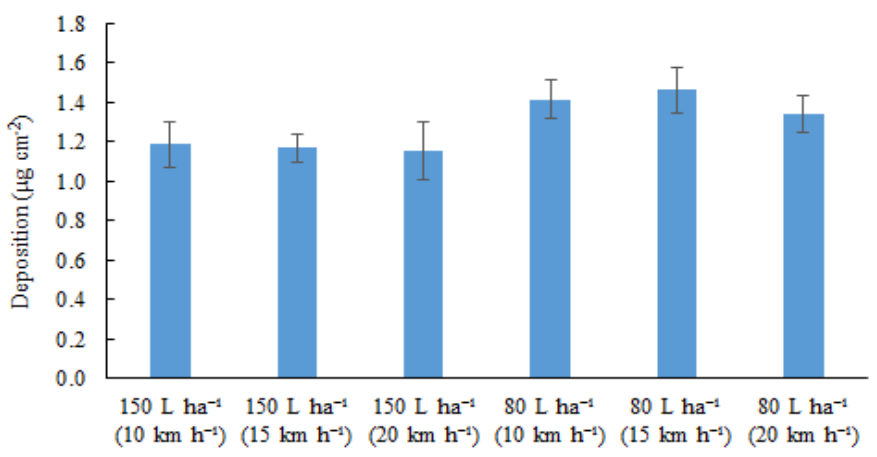

FIGURE 4. Quantity of marker $\left(\mu \mathrm{g} \mathrm{cm}^{-2}\right)$ retained in the upper leaves of soybean plants in function of applications with different speeds and application rates. The bars indicate the $\mathrm{CI}\left(\mathrm{CI}_{90 \%}\right)$.

In view of the results, it is verified that there is feasibility in the use of reduced application rates, close to $80 \mathrm{~L} \mathrm{ha}^{-1}$. However, such reduction requires appropriate application technology and constant monitoring of meteorological conditions in order to ensure the deposition of the plant protection product on the target and to minimize the losses to the environment.

The three speeds applied to the two application rates did not influence the deposition of the spray in the upper half of the canopy (Figure 4). Thus, the application at $20 \mathrm{~km} \mathrm{~h}^{-1}$ allows similar deposition at the apex of the plants when compared to the other speeds evaluated for the same application rate. Zaidan et al. (2012), evaluating the effect of different spray nozzles for high speed land applications on spray coverage and deposition in soybean plants, noted that the speed did not interfere with the application efficiency for nozzles with the same drop pattern, being the levels of deposits and coverage in the lower and middle thirds less than $50 \%$ of those obtained in the upper part of the plants.

The application rates (80 and $150 \mathrm{~L} \mathrm{ha}^{-1}$ ) and speeds $\left(10,15\right.$ and $\left.20 \mathrm{~km} \mathrm{~h}^{-1}\right)$ did not influence the amount of marker retained in the lower half of the soybean plants, as shown in Figure 5.

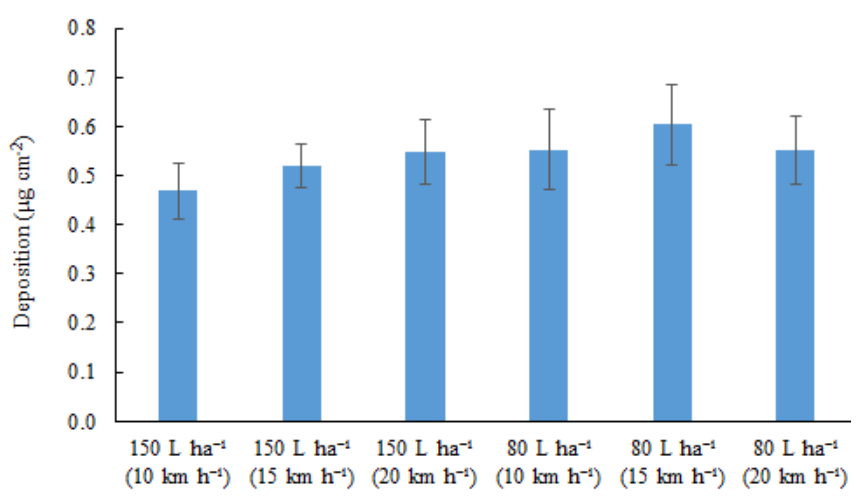

FIGURE 5. Quantity of marker $\left(\mu \mathrm{g} \mathrm{cm}^{-2}\right)$ retained in the lower leaves of soybean plants in function of applications with different speeds and application rates. The bars indicate the $\mathrm{CI}\left(\mathrm{CI}_{90 \%}\right)$. 
Similar results were found by Tavares et al. (2014), evaluating the spray deposition in the soybean crop in function of different application rates with the use of an auxiliary spray boom. Due to the tendency of the use of even lower application rates, terrestrial applications with a volume of $80 \mathrm{~L} \mathrm{ha}^{-1}$ and a speed of $20 \mathrm{~km} \mathrm{~h}^{-1}$ are feasible for farmers.

Berger-Neto et al. (2017), studying the control of white mold (Sclerotinia sclerotiorum Lib. De Bary) in soybean, found good control of the disease with the AI 110-02 nozzle with application rate of $100 \mathrm{~L} \mathrm{ha}^{-1}$. However, the authors used speeds of less than $8 \mathrm{~km} \mathrm{~h}^{-1}$. The authors recommended new studies with lower application rates.

Figure 6 shows the uniformity of the spray deposition in the canopy of soybean plants in function of the adopted application technology. The ratios between the upper and lower depositions tending to 1 denote penetration of the spray into the canopy of the more homogeneous plant, and, consequently, greater distribution uniformity along the canopy. There was no difference between the treatments for this variable.

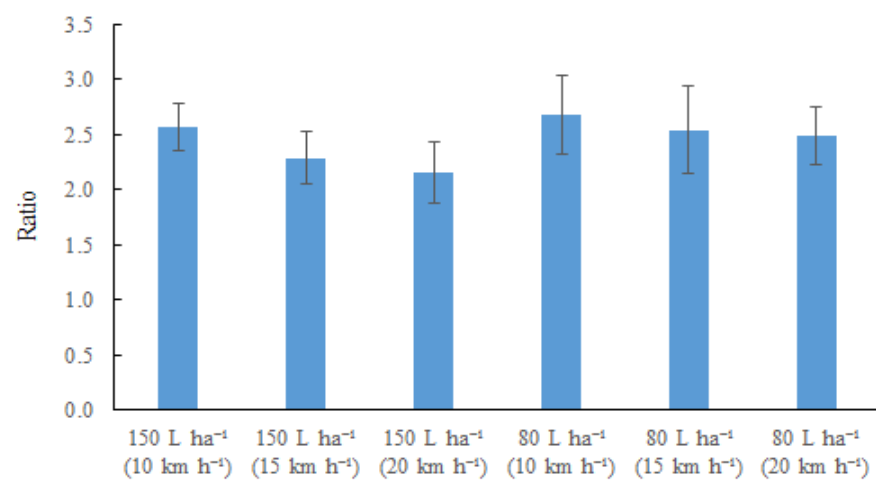

FIGURE 6. Ratio between the amount of marker retained in the upper and lower leaves of soybean plants in function of applications with different speeds and application rates. The bars indicate the $\mathrm{CI}\left(\mathrm{CI}_{90 \%}\right)$.

The data obtained showed the feasibility of using an application rate of $80 \mathrm{~L} \mathrm{ha}^{-1}$, associated with a speed of 20 $\mathrm{km} \mathrm{h}^{-1}$, taking into account the spray deposition. Due the good results obtained in this study, it is suggested to carry out new tests, taking into account the biological target, since in this case new variables will influence the results, such as the type of the product and its mode of action.

\section{CONCLUSIONS}

The use of spray nozzles of higher nominal flow, as well as lower pressures, generated droplets of larger sizes, reducing the drift potential.

The application rate of $80 \mathrm{~L} \mathrm{ha}^{-1}$, compared to 150 $\mathrm{L} \mathrm{ha}^{-1}$, generally provided equal and higher retention of the spray in the lower and upper leaves of the soybean plants, respectively.

The speeds did not influence the spray deposition.

\section{REFERENCES}

Antuniassi UR, Velini ED, Oliveira RB, Oliveira MAP, Figueiredo Z (2011) Systems of aerial spraying for soybean rust control. Engenharia Agrícola 31(4):695-703.
Baio FHR, Pettenan AL, Camolese HS, Gabriel RRF

(2016) Evaluation of spray deposits with twin flat tip with air induction in two soybean stages. Idesia 34(4):1-6.

Berger-Neto A, Jaccoud-Filho DS, Wutzki CR, Tullio HE, Pierre MLC, Manfron F, Justino A (2017) Effect of spray droplet size, spray volume and fungicide on the control of white mold in soybeans. Crop Protection 92(2):190-197.

Bueno MR, Cunha JPAR, Naves MG, Tavares RM (2014)

Deposição de calda e controle de plantas daninhas empregando pulverizador de barra convencional e com barra auxiliar, em volumes de calda reduzidos. Planta Daninha 32(2):447-454.

Bueno MR, Cunha JPAR, Roman RAA (2013) Tamanho de gotas de pontas de pulverização em diferentes condições operacionais por meio da técnica de difração do raio laser. Engenharia Agrícola 33(5):976-985.

Chechetto RG, Gandolfo MA, Voltan DS (2012)

Avaliação da retenção de calda de pulverização na cultura do milho com diferentes adjuvantes. Revista Científica Eletrônica de Agronomia 21(1):30-37.

Cunha JPAR, Juliatti FC, Reis EF (2014) Tecnologia de aplicação de fungicida no controle da ferrugem asiática da soja: resultados de oito anos de estudos em Minas gerais e Goiás. Bioscience Journal 30(4):950-957.

Cunha JPAR da, Silva RAM, Olivet JJ (2011) Nozzle and spray volume evaluation on soybean (Glycine max (L.) Merrill) fungicide application. Revista de la Facultad de Agronomía 28(3):344-359.

Cunha JPAR, Teixeira MM, Vieira RF, Fernandes HC, Coury JR (2004) Espectro de gotas de bicos de pulverização hidráulicos de jato plano e de jato cônico vazio. Pesquisa Agropecuária Brasileira 39(10):977-985.

Gandolfo MC, Chechetto RG, Carvalho FK, Gandolfo UR, Moraes ED (2013) Influência de pontas de pulverização e adjuvantes na deriva em caldas com glyphosate. Revista Ciência Agronômica 44(3):474-480.

Liu Q, Cooper SE, Qi L, Fu Z (2006) Experimental study of droplet transport time between nozzles and target. Biosystems Engineering 95(2):151-157.

Madureira RP, Raetano CG, Cavalieri JD (2015) Interação pontas-adjuvantes na estimativa do risco potencial de deriva de pulverizações. Revista Brasileira de Engenharia Agrícola e Ambiental 19(2):180-185.

Tavares RM, Cunha JPAR, Naves MG, Bueno MR, Alves GS (2014) Deposição de calda em plantas de soja empregando pulverizador com barra convencional e barra auxiliar. Revista Agrotecnologia 5(1):87-104.

Tormen NR, Silva FDL, Debortoli MP, Uebel JD, Fávera DD, Balardin RS (2012) Deposição de gotas no dossel e controle químico de Phakopsora pachyrhizi na soja. Revista Brasileira de Engenharia Agrícola e Ambiental 16(7):802-808. 
Viana RG, Ferreira LR, Ferreira MC, Teixeira MM, Rosell JR, Tuffi Santos LD, Machado AFL (2010) Distribuição volumétrica e espectro de gotas de pontas de pulverização de baixa deriva. Planta Daninha 28(2):439-446.

Souza RT, Constantin J, Velini ED, Montorio GA, Maciel CDG (2002) Seletividade de combinações de herbicidas latifolicidas com lactofen para a cultura da soja. Scientia Agrícola 59(1):99-106.
Yokomizo GKI, Duarte JB, Vello NA, Unfriend JR (2013) Análise AMMI da produtividade de grãos em linhagens de soja selecionadas para resistência à ferrugem asiática. Pesquisa Agropecuária Brasileira 48(10):1376-1384.

Zaidan SE, Gadanha Júnior CD, Gandolfo MA, Pontelli CO, Mosquini WW (2012) Desempenho de pontas de pulverização em aplicações terrestres com alta velocidade. Engenharia Agrícola 32(6):1126-1132. 